\title{
Professional Career Choice and Career Start in Regards to the Expectations of Hungarian Law Enforcement Higher Education and of the Law Enforcement Organs
}

\author{
Ákos Erdös \\ ORCID: 0000-0001-9805-3511 \\ Adrienn Magasvári \\ ORCID:0000-0002-3737-0246 \\ Andrea Szabó \\ ORCID: 0000-0002-8224-4089 \\ National University of Public Service, Hungary
}

\begin{abstract}
The aim of this study is to present the Faculty of Law Enforcement of the National University of Public Service and the admission process awaiting the members of generation Z — and within it, those who wish to apply for officer cadet status as well as the drop-out rates and their causes following successful admission, and also the prerequisite base competences expected within the framework of public service and in law enforcement. The young applicants admitted to the Faculty of Law Enforcement are supposed to represent a significant proportion of the future reinforcement of the professional service personnel, thus the member of generation Z not only stand at the gates of higher education but at the gates of the law enforcement labour market, too. Through our study, we would like to highlight the correlations emerging between the competence-based expectations of the law enforcement organs from the young career starters and the university admission process as well as the individual wishes of the applicants, and the level of contrast or synergy of the physical and intellectual status of the students in this matter. From this perspective, the question may arise whether it is necessary to implement any changes in the set of conditions, expectations or attitudes regarding the higher educational training or in the starting phase of the law enforcement career path.
\end{abstract}

DOI: 10.5604/01.3001.0014.6702

http://dx.doi.org/10.5604/01.3001.0014.6702

Keywords: personnel reinforcement, generational characteristics, skills, abilities, professional service

\section{Introduction}

The Faculty of Law Enforcement of the University of Public Service - similarly to its legal predecessor, the Police College - undertakes the unique task of conducting law enforcement training in Hungary. The Faculty fulfills the task of training graduate young professionals, commissioned officers, public servants and officials primarily for state law enforcement organs, such as the Hungarian Police Force, the Hungarian Prison Service, the National Tax and Customs Administration, the National Directorate-General for Disaster Management, the Immigration and Asylum Office as well as for private security firms. According to the career path tracking system about $98 \%$ of the university graduates get a job offer. The reason behind this great figure is that the officer cadet students - police, customs or disaster management officers - pursue their studies holding a study contract with the contracting law enforcement organisations, which undertake 
the responsibility of hiring them after graduation; the migration-profile training is also based on a scholarship contract system, while the security studies graduates mostly get jobs either at private personal and property protection security firms, at nature protection guards' organisations, at armed security personnel firms, or in various positions offered by the public land management agency. All of this highlights the fact that the $98 \%$ hiring rate of the new graduates is due to the scholarship contracts, and may also be a consequence of the specially customised training scheme provided for the needs of the law enforcement and security organisations.

A successful career start may also be determined by various factors. The generational characteristics of the young applicants aiming to become law enforcement agents, the admission process of the law enforcement higher education, and the first year experiences of the law enforcement training together have a significant impact on the outcome of who will actually be able to start practicing their profession. Thus, in the following pages, we present the form and manifestations of these determinants within the Hungarian law enforcement higher education system, relying on our own research findings.

\section{Generational characteristics, special expectations}

First of all, it is primarily necessary to investigate the attitudes, basic features, competences of the members of the generation who at present or in the nearfuture tend to apply for law enforcement higher education or would likely show up in the law enforcement career system, and whether these attributes correlate with the expectations and prerequisites of the law enforcement organisations.

It is nevertheless a fact that forming a competitive public service scheme and law enforcement administration is not only a matter of economic policy measures. Appropriate state operation demands the existence of a suitable quantity and quality of human resources, as well. Consequently, a competitive future law enforcement administration needs a qualified, skillful labour force. For the appropriate high level law enforcement service provision, we need to address the problem of generation shift, and the skillful members of the new generation must be attracted to the public service sector and should be preserved and kept there, as well.' To cope with these ensuing problems, it is indispensable that the law enforcement and state administration organisations should deal with human resource reinforcement issues as being of outstanding importance.

There have not been any surveys for quite a long time regarding the competence prerequisites from the job applicants aiming to serve in the public service sector. Project No. KÖFOP 2.1.5-VEKOP-16-2016-0001 entitled 'Strategic support of personnel reinforcement within the competitive public sector' was elaborated to address this specific problem ${ }^{2}$, also sharing an important element - among

1 Szabó S, Biba S, A munkáltatói márka szerepe a közszolgálatban, különös tekintettel az y-z generációra. Munkaügyi Szemle online (6), 2015, p. 17. Electronic source: http://www. munkaugyiszemle.hu/sites/default/files/elofizetes/02961506.pdf, accessed: 27.09.2019.

2 Under the guidance of the Ministry of the Interior, the research on base-competences was launched in 2016 as the project code-named KÖFOP-2.1.5-VEKOP-16-2016-0001 and entitled 'Strategic support of the personnel reinforcement in the competitive public service'. 
others - amely the establishment of the basis for a competence-based admission process system. ${ }^{3}$

Within the framework of the preselection phase of the project, under the supervision of the Ministry of the Interior, so-called base-competence research was initiated in 2017, aiming to define the unified admission competence framework for anyone interested in entering the public service.

The research group, after acquainting themselves with the primary literature analysis and organisational experiences aiming to reveal the base-competences, called for the method of applying focus-group interaction as well as of half-structured interviews and questionnaire-based data collection.

The research survey involved the examination of both the law enforcement and state administration leaders as well as their colleagues with directing functions in the organisations.

Following the content-based analysis of the interviews, the research-group compiled a competence list of 19 elements with special behavioural attributes attached. The questionnaire focussed on the primary opinion of the people in charge - in managing, coordinating, supervising, controlling and leadership positions - on the ideal attributes, personal characteristics and set of competences for people who wish to be hired in the public service sector (specifically within state administration or law enforcement).

The questionnaire was fully completed by a total of 1,443 colleagues and as a result, a competence list of 10 attributes and their manifestation patterns has been proposed.

Finally, following the guided conversations conducted within the focus-group, the definition of each competence was elaborated, together with the behavioural patterns attached to them.

Since the research aimed to define both the public service base competences and the specialised law enforcement and state administration competences, multiple composition focus-groups had to be set up. As a result of the work of the focus-groups, a 12-element competence list was elaborated, which was welcomed by all parties and was acceptable and applicable in all special fields involved.

The results of the research do properly reflect what kind of attributes, competences, skills and personality traits the leaders of the public service organisations consider important (see: Table 1). But what about the features of the present career starter generation? In what ratio do they manage to comply with these expectations? Since they are already members of generation $Z$, with different attitudes, viewpoints and habits of the mind. They tend to be the children of smaller, nuclear families having mothers with the highest average age. With the increasing importance of individualism and of self-achievement, these people tend to share narcissistic personality traits, too. Furthermore, their social compliance and integration skills appear to be diminishing constantly, and they also seem to be less and less tolerant ${ }^{4}$. The current career starters are less motivated by the stability and reliability of their professions, moreover they wish for a large range of career choices and alternative

\footnotetext{
${ }^{3}$ Malét-Szabó E, Hegyi H, Hegedűs J, Szeles E, Ivaskevics K, Rendőri alapkompetenciák az egységes közszolgálati alapkompetenciák tükrében. Rendőrségi Szemle, A rendőrség Tudományos Tanácsának folyóirata, l. évfolyam, 1. szám, 2017, p. 24.

${ }^{4}$ Twenge J.M, Campbell S.M, Generational differences in psychological traits and their impact on the workplace. Journal of Managerial Psychology, 2008, Vol. 23, No. 8, pp. 862-877.
} 
directions. ${ }^{5}$ Their self-esteem is much stronger than of those from the previous generations, and consequently their expectations tend to be much higher, as well. They expect high wages and quick career advancement, because quite often, they overestimate their own performance. ${ }^{6}$ Typically, these young people come to the labour market with considerably higher wage expectations that can be fulfilled within the public service sector only through the commissioned professional service and by the state administration officials, while on the other hand, state administration officials' pay checks tend to be falling behind those of the business sector. ${ }^{7}$

Workplaces abounding in success, versatile experiences and tasks, recognition and quick feedback, appropriate treatment and response, preferably instantly, seem to be of utmost importance for them. Not getting what they expect, they tend to swap jobs and positions quickly, since workplace adherence, discipline, respect for rules and authority are not supposed to be their strength.

They do not really seem to be persistent, and also lack stamina and the strength to face failures, yet their self-esteem is fairly high, which results in a low level of commitment. Therefore, it reveals that the organisational expectations, needs and wishes of the career starters do not seem to be in perfect harmony and concord.

\section{Characteristics of the officer cadet legal status and of the admission process into law enforcement higher education}

To elaborate further on the topic, it seems to be indispensable to briefly outline the newly implemented legal status within the law enforcement higher education system, which is meant to be called the officer cadet status.

Most likely, everyone has already heard the revered wisdom from the older generation that 'A smooth sea does not make a skilled sailor'. Naturally, we tend to hear this proverb when we complain about the hardships of life, work or education. The moral of the old wisdom tends to refer to the realisation that one's body, soul and spirit ${ }^{8}$ and overall personality can be improved and developed properly

${ }^{5}$ Hazafi Z, Néhány gondolat a közigazgatás munkaerő-piaci versenyképességéről. Hadtudomány XXV. évfolyam, elektronikus különszám. HR Megoldások a XXI. században — nemzetközi kitekintéssel — fókuszban a közszféra és a magánszféra című szakmai-tudományos konferencia, 2015. p. 15. Electronic source: http://mhtt.eu/hadtudomany/2015/2015_elektronikus_kulonszam/4_HAZAFI_ZOLTAN.pdf, accessed: 28.11.2019.

${ }^{6}$ Magasvári $A$, What is a good entrant into the labour market? Tudásmenedzsment, 2018, Vol. 19, No. 2, p. 128. Electronic source: http://btk.pte.hu/sites/btk.pte.hu/files/files/xix. evf_.2.szam_.pdf, accessed: 26.11.2019.

7 Krauss F.G, A civil közigazgatás bérrendszerének megújulása és fenntarthatósága. Budapesti, 2019. Kereskedelmi és Iparkamara Gazdasági Szolgáltatások Tagozat, XX. Tanácsadó Osztály, 2016, pp. 99-101.

8 'According to Socrates - claimed by Safranski - everything should possess consciousness so as to be good...', [in:] B, Kognitív esztétika, mint pszichológiai határhelyzet (avagy olvasta-e Nietzsche Kierkegaard-t?) Kritische Zeiten - Zeitschrift für Humanwissenschaften. 2015, T. 6, Vol. 1-2, Januar-Juli, Wien, p. 37. 
against a certain level of hardship, challenges and probes, and as a result of these, the human perseverance, resilience and problem solving skills can also improve. ${ }^{9}$

This proverb may be absolutely true for the newly admitted students $\mathbb{\nabla}$ with

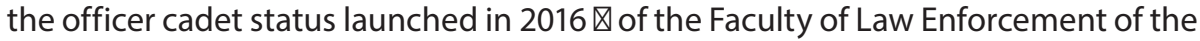
National University of Public Service, since they must face challenges they have never encountered before in their lives.

It could be the permanent uniform obligation even during in-class studies, or the morning line-up, the continuous shooting practice and physical prep-trainings, as well as the late-afternoon classes..$^{10}$

The officer cadet status constitutes a special transition between the previously applied student and professional commissioned servicemen status. We can find versatile forms of evidence to prove this claim in legal directives and internal regulations concerning the establishment and the rights and duties of the officer cadets, precisely until the terms under which this legal relationship would cease, and furthermore, it contains directives concerning its relationship to other student legal statuses in similar institutions. ${ }^{11}$

Thus, the officer cadet may be placed in a special legal status category very similar but not identical to the commissioned service people's legal relations. The legal status of the officer cadets proves to be a new legal institution aiming to provide new legal guarantees for the students as well as to support them financially and facilitate their studies.

The officer cadet student, by signing the scholarship contract, pledges to follow his/her studies according to his/her best skills and abilities. The law enforcement organisation pledges to support the studies of the officer cadet, to hire him/her after a successful graduation as well as to offer him/her an appropriate professional position within the organisation.

Consequently, the officer cadet and student legal status must be equivalent and both must be valid along the whole length of the studies. Cessation of any of the two may result in losing the other's legal status, as well. Naturally, as a primary prerequisite, to initiate officer cadet status, first of all, the student must be admitted into the law enforcement higher education system.

The university admission process shows no alteration whatsoever from the other valid higher educational admission processes. Some conditions, though, must be emphasised, e.g. for the full-time law enforcement training schemes, only those Hungarian citizens may apply who are aged above 18 years but are under 25 years in the year of admission, and possess permanent residency in Hungary.

Most of the full-time educational schemes have the prerequisite from the applicants to possess an intermediate (B2) level state-accredited complex language certificate or an equivalent Matura exam certificate ${ }^{12}$. This seems to be

${ }^{9}$ Mikolicz G, Teher alatt nő a pálma. Sub pondere crescit palma. Electronic source: http:// www.bibliaszov.hu/index.php?option=com_content\&view=article\&id=66\%3Ateher-alatt-na-palma\&ltemid=21, accessed: 12.11.2019.

10 Szabó A, Sub pondere crescit palma, avagy a pénzügyőr tisztjelölt erőpróbája, [in:] Dobák I, Hautzinger Z (Eds), Szakmaiság, szerénység, szorgalom: Ünnepi kötet a 65 éves Boda József tiszteletére Budapest, Magyarország: Dialóg Campus Kiadó, Nordex Kft., 2018, p. 599.

${ }^{11}$ Ibid., p. 600.

12 Since 2016, applicants must have a lg. certificate from any of the official languages of the EU or from Ukrainian, Serbian, Boyash, Lovaric, Russian or Chinese languages. 
reasonable as the cadets at the Faculty of Law Enforcement will usually not have the opportunity to develop their foreign language skills when they start working as commissioned officers, while, in many cases, they need them for work..$^{3}$ Some experts do claim that the best way to improve and deepen the foreign language knowledge of the students would be to make them attend a foreign language course in each semester in any chosen language. ${ }^{14}$ Furthermore, it is also important to highlight that in the case of full-time officer cadet applicant students, they must pass a strict physical, psychological aptitude test. Failing any part of this test, even with outstanding educational records, excludes the applicant from the law enforcement admission process. Finally, as part of the admission process, there is also a personal professional aptitude interview assessing the applicant's personal motivation for the law enforcement profession as well as checking/revealing any causes that might exclude him/her from this special career choice.

The officer cadet, after the successful admission process, may start his/her law enforcement base training, when the law enforcement organisation sets a six-month long trial period. During the trial period, both parties may arbitrarily and straightforwardly cease or step away from the contract. Moreover the officer cadet's legal status must be ceased in the case that the cadet does not comply with the basic requirements of the law enforcement training due to his/her personal fault. ${ }^{15}$

\section{Experiences of the admission process and of the law enforcement basic preparation training}

The experiences of the previous years (2016-2018) have already demonstrated that the members of generation Z tend to identify and comply even with the basic prerequisites of the law enforcement admissions process and the demands of the newly established officer cadet legal status with difficulties. Quite a considerable number of students do not want to or cannot overcome these strict requirements and challenges. Analysing the results of the admission process and the findings of the first period of the law enforcement training, we have come to confirm the following claims.

The drop-out rate at the physical aptitude test is continuously rising each year. In 2016, 30.9\% of the applicants, and in 2017,24.4\% received an unfit (failed) qualification along the physical aptitude test, while in 2018 the disqualification ratio rose to $43 \%$.

Presumably, the reasons behind the significant proportion of unfit applicants for the physical aptitude tests must be multiple. What is certain is the fact stemming

${ }_{13}$ See the results of the survey conducted within the border policing branch of the Hungarian Police: Borszéki J, A Rendőrség határrendészeti feladatokat ellátó állományának idegen nyelvi ismeretei és érdeklődése a nemzetközi határrendészeti tevékenységek iránt, [in:] Szelei I, Berki G (Eds), A hadtudomány és a 21. század. Tanulmánykötet, 2015, pp. 163-196.

${ }^{14}$ Nikolov M, Az idegen nyelvek tanulása és a nyelvtudás. Magyar Tudomány. A Magyar Tudományos Akadémia folyóirata. Alapítva: 1840. 2011/9. Budapest, 2011. p. 1056. Electronic source: http://www.matud.iif.hu/2011/09/04.htm, accessed: 17.11.2019.

15 Szabó A, A tisztjelölti jogállás sajátosságai, [in:] Erdős Á (Ed.), Integrált pénzügyőri ismeretek Kezdő I pénzügyőrök kézikönyve. Budapest, Magyarország: Magyar Rendészettudományi Társaság Vám- és Pénzügyőri Tagozat, 2018, p. 303. 
from the authentic representative national survey carried out among Hungarian school children showing that Hungarian kids sadly enough pursue an extremely static lifestyle poor in any kind of physical activity. ${ }^{16},{ }_{17}$

Another reason might be that the applicants may not prepare for the examinations and tests, do not test their skills and fitness, endurance, and in some cases they are not really aware of their physical performance and abilities or they tend to overestimate those.

My previous research findings have clearly revealed that adolescents have consistently overestimated their activities and physical performance - even four times higher than actual reality would demonstrate..$^{18,19}$

However, the health status and psychical aptitude test results reflect a more favourable situation.

The numeric data from the previous years do confirm that among the applicants for law enforcement officer training, the ratio of physically or psychologically unfit students has been shrinking. From the students showing up at health and psychological examinations, $24.3 \%$ received unfit status in 2016, while in 2017, it was $21 \%$, and in 2018 , only $19 \%$ of them proved to be unfit for service.

Finally, the last phase of the admission process is supposed to be the professional aptitude interview or an orientative discussion. The experiences reflect that from among the participants in these orientative discussions, the ratio of unfit qualified applicants does not reach even 1\% (in 2016, 1.08\%; in 2017, 0.97\%; in 2018, $0.63 \%$ of the applicants).

All the same, the first really feasible manifestation of the discrepancy between the expectations of the law enforcement professional services and the ones of the members of generation $\mathrm{Z}$ emerges during the first 5 -week-long basic law enforcement training period.

Along the first 5-week-long session, the training takes place under strict rules - even the first weekend must be spent confined together in the institution for the enlisted personnel. The numeric feedbacks and experiences of the previous years do confirm our assumption that during this first 5-week-long basic preparatory training session of the law enforcement training, increasing numbers of students decide to leave the officer cadet profession. Each year, on average 15.8\%, of the officer cadets' personnel leave the institution, particularly during the first 5-week training session (in 2016, 11.9\%; in 2017, 16.2\%; while in 2018, 19.4\%).

16 Németh A, Fizikai aktivitás és képernyőhasználat, [in:] Németh A, Költő A (Eds), Egészség és egészségmagatartás iskoláskorban 2014. Az Iskoláskorú gyermekek egészségmagatartása elnevezésű, az Egészségügyi Világszervezettel együttműködésben megvalósuló nemzetközi kutatás 2014. évi felméréséről készült nemzeti jelentés. Nemzeti Egészségfejlesztési Intézet. Budapest, 2014, pp. 31-45.

17 World Health Organization Global recommendations on physical activity for health. WHO Press. Genava, 2010.

${ }_{18}$ Csányi T, A fiatalok fizikai aktivitásának és inaktív tevékenységeinek jellemzői. (Characteristics of the physical actions and inactive activities of young people). Új Pedagógiai Szemle, 2010, Vol. 60, Issue 3-4, pp. 115-128.

${ }_{19}$ Mcmurray R.G, Ring K.B, Treuth M.S, Welk G.J, Pate R.R, Schmitz K.H, Pickrel J.L, Gonzalez V, Almedia M.J, Young D.R, Sallis J.F, Comparison of two approaches to structured physical activity surveys for adolescents. Medicine \& Science in Sports \& Exercise, 2004, Vol. 36, Issue 12, pp. 2135-2143. 
To reveal the possible reasons for the early leavers and the high drop-out rate, we carried out a content analysis based on the reports filled out by the discharging officer cadets, and as a result, we obtained 65 feedbacks fit for evaluation. ${ }^{20}$ From the officer cadets in the sample, 50 persons used to belong to the Police Force, 13 persons to the National Tax and Customs Administration, and 2 more students to the National Directorate-General for Disaster Management personnel, and they decided to give up their studies and leave those organisations during the first 5 -week training session. These officer cadets took part in the basic law enforcement preparatory training on average for 6.7 days.

As a result of our content-analysis, we came to the conclusion that the various discharging reasons may fall into the following 5 categories (Groups of reasons for career drop-out):

1. Low level of sense of duty and compliance with the rules;

2. Wrong career choice;

3. Exaggerated personal pledge;

4. Health unfitness;

5. Miscellaneous.

Behind the category of low level of sense of duty and compliance with the rules lies the primary reason correlated with rejecting the duties, obligations stemming from the law enforcement profession's basic features as well as of the officer cadets' primary characteristics.

Almost one-third (35.3\%) of the leaving cadets claimed this reason as the primary cause for completing their discharge declaration. Based on the previously mentioned observations, we might as well assume that the low level of compliance with the rules and sense of duty tightly correlates with the primary features of members of generation $Z$.

We have listed in the wrong career choice category all those factors which could be traced back to external impacts, such as the influence of parents or an immature and unprepared decision for the law enforcement career choice. Some of the students ending up in the wrong career choice category had deliberately applied for the law enforcement profession on superficial and ill-considered grounds. Moreover, some other groups of students obeyed external pressure, predominantly from their parents, when signing up for law enforcement training. This kind of cause emerged in $29.2 \%$ of the discharging reasons.

A significant amount of the career leavers (23\%) explained their withdrawal from this profession claiming to be unprepared or unfit to properly comply with the requirements of thelawenforcement profession (personal overburden or exaggerated pledge).

Another group of reasons in $29.3 \%$ behind the drop-out students proved to be their unfit health condition. Students who got injured during the preparatory session and could not carry on with the training also fall into this category. Furthermore, we have also listed here the cadets who possessed some previously concealed diseases, symptoms or injuries which emerged or were revealed in the course of the training tasks.

Finally, all of those reasons which could not be listed into any of the categories from above fall into the miscellaneous category (7.6\%).

${ }^{20}$ Erdős Á, A rendészeti tisztté válás első nehézségei. A gyermeki elképzelések találkozása a realitással. Manuscript, under construction, 2018. 


\section{Conclusions}

On the one hand, in our study, we have intended to present the current situation of Hungarian law enforcement higher education. On the other hand, we have also wished to pinpoint one of the major challenging phenomena that Hungarian law enforcement higher education must face, namely the difficulties of integrating members of generation $\mathrm{Z}$ into the law enforcement structures and all of the other jeopardising factors.

The research findings published in the study paper may also foster a better understanding of the importance for Hungarian law enforcement officer training as well as for the entire law enforcement profession of analysing the primary generational features, attitudes, and visions of the young people who wish to apply for the law enforcement career. The kind reader might as well get some other guidelines, hints concerning the possible or desirable changes, transformations which should be implemented in terms of training, admission process, practical expectations and sets of criteria in the matter, since it clearly reveals that the skills, abilities and attitudes of the young people show considerable discrepancies with both the organisational and the training requirements. Furthermore, since the members of generation $Z$ have already knocked on the doors of the labour market, both the law enforcement higher education and the human resource management bodies of the law enforcement organisations must take into consideration the generational features of the applicants; moreover their expectations and demands ought to be tackled. We must be ready to take new measures in the preparatory training, and the law enforcement organisations should also change their integrational and retention strategies.

Table 1. Unified public service competences

\begin{tabular}{|c|l|l|}
\hline $\begin{array}{c}\text { Rank } \\
\text { No. }\end{array}$ & \multicolumn{1}{|c|}{ Name } & \multicolumn{1}{c|}{ Definition } \\
\hline I. & $\begin{array}{l}\text { Decision-making } \\
\text { skills }\end{array}$ & $\begin{array}{l}\text { Recognises the situations apt for decision-making, } \\
\text { and based on the available information, makes the most } \\
\text { optimal decision in that circumstance. }\end{array}$ \\
\hline II. & Co-operation & $\begin{array}{l}\text { So as to fulfill and perform his/her tasks, he/she coordinates } \\
\text { his/her actions and behaviour with others. }\end{array}$ \\
\hline III. & $\begin{array}{l}\text { Emotional } \\
\text { Intelligence }\end{array}$ & $\begin{array}{l}\text { Recognises and comprehends his/her own and other } \\
\text { people's emotional states, and is able to cope properly } \\
\text { with the actions stemming from these emotions according } \\
\text { to the situation. }\end{array}$ \\
\hline IV. & Responsibility & $\begin{array}{l}\text { During task execution, is able to recognise, preserve } \\
\text { and undertake the consequences of his/her actions } \\
\text { and decisions, and is able to report on them. }\end{array}$ \\
\hline V. & $\begin{array}{l}\text { Resoluteness, } \\
\text { self-confidence }\end{array}$ & $\begin{array}{l}\text { Is able to perform the objectives of the organisation } \\
\text { resolutely, taking into account his/her capacities } \\
\text { and opportunities. }\end{array}$ \\
\hline VI. & Efficient labour & $\begin{array}{l}\text { Is able to fulfill his/her tasks responsibly and cautiously, } \\
\text { and to optimally apply and adopt his/her resources at hand. }\end{array}$ \\
\hline
\end{tabular}




\begin{tabular}{|c|l|l|}
\hline VII. & $\begin{array}{l}\text { Communication } \\
\text { skills }\end{array}$ & $\begin{array}{l}\text { Is able to communicate properly and clearly in speech } \\
\text { and writing according to the situation, and to interpret } \\
\text { and comprehend others' communication. }\end{array}$ \\
\hline VIII. & $\begin{array}{l}\text { Conflict } \\
\text { management }\end{array}$ & $\begin{array}{l}\text { Is able to apply such a style and manner in an antagonistic } \\
\text { situation through which the conflict can be mitigated. }\end{array}$ \\
\hline IX. & Self-reliability & $\begin{array}{l}\text { Based on his/her knowledge and experiences, is able } \\
\text { to carry out his/her allocated task without continuous direct } \\
\text { control and supervision. }\end{array}$ \\
\hline X. & $\begin{array}{l}\text { Problem-solving } \\
\text { skills }\end{array}$ & $\begin{array}{l}\text { Is able to identify and offer solutions to emerging problems. } \\
\text { From the possible alternatives, is able to select the best } \\
\text { solution for the optimal outcome. }\end{array}$ \\
\hline XII. & $\begin{array}{l}\text { Psychological } \\
\text { resilience }\end{array}$ & $\begin{array}{l}\text { Is capable of preserving and performing his/her operability } \\
\text { even in challenging, difficult situations. }\end{array}$ \\
\hline
\end{tabular}

Source: Malét-Szabó E, Hegyi H, Hegedűs J, Szeles E, Ivaskevics K, Rendőri alapkompetenciák az egységes közszolgálati alapkompetenciák tükrében. Rendőrségi Szemle, A Rendőrség Tudományos Tanácsának folyóirata, I. évfolyam, 1. szám, 2017, pp. 66-68.

\section{References}

6. Malét-Szabó E, Hegyi H, Hegedűs J, Szeles E, Ivaskevics K, Rendőri alapkompetenciák az egységes közszolgálati alapkompetenciák tükrében. Rendőrségi Szemle, A Rendőrség Tudományos Tanácsának folyóirata, I. évfolyam, 1. szám, 2017.

7. Mcmurray R.G, Ring K.B, Treuth M.S, Welk G.J, Pate R.R, Schmitz K.H, Pickrel J.L, Gonzalez V, Almedia M.J, Young D.R, Sallis J.F, Comparison of two approaches to structured physical activity surveys for adolescents. Medicine \& Science in Sports \& Exercise, 2004, Vol. 36, Issue 12.

8. Csányi T, A fiatalok fizikai aktivitásának és inaktív tevékenységeinek jellemzői. . Új Pedagógiai Szemle, 2010, Vol. 60, Isuue 3-4.

9. Németh A, Fizikai aktivitás és, [in:] Németh $A$, Költő $A$ (Eds), Egészség és egészségmagatartás iskoláskorban 2014. Az Iskoláskorú gyermekek egészségmagatartása elnevezésű, az Egészségügyi Világszervezettel együttműködésben megvalósuló nemzetközi kutatás 2014. évi felméréséről készült nemzeti jelentés. Nemzeti Egészségfejlesztési Intézet, Budapest, 2014

10. Szabó A, A tisztjelölti jogállás sajátosságai, [in:] Erdős Á (Ed.), Integrált pénzügyőri ismeretek I. Kezdő pénzügyőrök kézikönyve. Budapest, Magyarország: Magyar Rendészettudományi Társaság Vám- és Pénzügyőri Tagozat, 2018.

11. Borszéki J, A Rendőrség határrendészeti feladatokat ellátó állományának idegen nyelvi ismeretei és érdeklődése a nemzetközi határrendészeti tevékenységek iránt, [in:] Szelei I, Berki G (Eds), A hadtudomány és a 21. század. Tanulmánykötet, 2015.

12. Nikolov M, Az idegen nyelvek tanulása és a nyelvtudás. Magyar Tudomány. A Magyar Tudományos Akadémia folyóirata. Alapítva: 1840. 2011/9. Budapest, 2011. p. 1056. Electronic source: http://www.matud.iif.hu/2011/09/04.htm 
13. Szabó A, Sub pondere crescit palma, avagy a pénzügyőr tisztjelölt erőpróbája, [in:] Dobák I, Hautzinger Z (Eds), Szakmaiság, szerénység, szorgalom: Ünnepi kötet a 65 éves Boda József tiszteletére Budapest. Magyarország: Dialóg Campus Kiadó, Nordex Kft., 2018

14. Mikolicz G, Teher alatt nő a pálma. Sub pondere crescit palma. Electronic source: http://www.bibliaszov.hu/index.php?option=com_content\&view=article\&id=6 6\%3Ateher-alatt-n-a-palma\&ltemid=21

15. Balassa B, Kognitív esztétika, mint pszichológiai határhelyzet (avagy olvastae Nietzsche Kierkegaard-t?) Kritische Zeiten - Zeitschrift für Humanwissenschaften. 2015, T. 6, Vol. 1-2, Januar-Juli, Wien.

16. Twenge J.M, Campbell S.M, Generational differences in psychological traits and their impact on the workplace. Journal of Managerial Psychology, 2008, Vol. 23, No. 8.

17. Hazafi Z, Néhány gondolat a közigazgatás munkaerő-piaci versenyképességéről. Hadtudomány XXV. évfolyam, elektronikus különszám. HR Megoldások a XXI. században — nemzetközi kitekintéssel — fókuszban a közszféra és a magánszféra című szakmai-tudományos konferencia, 2015. p. 15, Electronic source: http://mhtt. eu/hadtudomany/2015/2015_elektronikus_kulonszam/4_HAZAFI_ZOLTAN.pdf

18. Krauss F.G, A civil közigazgatás bérrendszerének megújulása és fenntarthatósága. Budapesti Kereskedelmi és Iparkamara Gazdasági Szolgáltatások Tagozat, XX. Tanácsadó Osztály, 2016.

19. Szabó S, Biba S, A munkáltatói márka szerepe a közszolgálatban, különös tekintettel az y-z generációra. Munkaügyi Szemle, 2015, Vol. 6.

20. Electronic source: http://www.munkaugyiszemle.hu/sites/default/files/elofizet es/02961506.pdf

21. Magasvári $A$, What is a good entrant into the labour market? Tudásmenedzsment, 2018, Vol. 19, No. 2.

22. Electronic source: http://btk.pte.hu/sites/btk.pte.hu/files/files/xix.evf_.2.szam_ ERDŐS, Ákos: A rendészeti tisztté válás első nehézségei. A gyermeki elképzelések találkozása a realitással. Manuscript, under construcition, 2018.

\section{About the Authors}

Ákos Erdös, Assistant lecturer of the Department of Customs and Finance Guard, Faculty of Law Enforcement, National University of Public Service, Budapest, Hungary, Ph.D. student of the Doctoral School of Law Enforcement, Substance Abuse Consultant, Finance Guard Major at the National Tax and Customs Administration. Academic/research interests: law enforcement, addiction.Email:erdos.akos@uni-nke.hu

Adrienn Magasvári, Lecturer of the Department of Customs and Finance Guard, Faculty of Law Enforcement, National University of Public Service, Budapest, Hungary, Ph.D. student of the Doctoral School of Public Administration Sciences, Finance Guard Lieutenant-Colonel at the National Tax and Customs Administration. Academic/research interests: law enforcement, human resource management, generation management.Email: magasvari.adrienn@uni-nke.hu

Andrea Szabó, PhD, Assoc. Prof., Head of the Department of Customs and Finance Guard, Faculty of Law Enforcement, National University of Public Service, Budapest, Hungary, Finance Guard Colonel at the National Tax and Customs Administration. Academic/research interests: law enforcementhighereducation, customs officers'highereducation.Email:szabo.andrea@uni-nke.hu 
Streszczenie. Celem niniejszego artykułu jest przedstawienie Wydziału Prawa i Administracji Państwowej Wyższej Szkoły Służby Publicznej oraz procesu rekrutacji na studia przedstawicieli pokolenia Z, którzy chca jednocześnie ubiegać się o status kadeta. Autorzy prezentują wskaźniki rezygnacji ze studiów i ich przyczyny po pomyślnym przyjęciu kandydata, a także podstawowe kompetencje wymagane w służbie publiczneji organach ścigania. Młodzi kandydaci przyjmowani na Wydział Prawa i Administracji majq stanowić istotnq część przyszłej kadry w służbie publicznej, dlatego też przedstawiciel pokolenia Z nie tylko stoje u progu wyższej uczelni, ale także wchodzi na rynek pracy organów ścigania. Dzięki przeprowadzonym badaniom Autorzy pragna zwrócić uwagę na pojawiające się korelacje pomiędzy oczekiwaniami organów ścigania dotyczącymi kompetencji młodych osób rozpoczynających karierę zawodową a procesem przyjmowania na studia oraz indywidualnymi życzeniami kandydatów, a także poziomem kontrastu lub synergii stanu fizycznego i intelektualnego studentów. Może zatem pojawić się pytanie, czy jest konieczne wprowadzenie jakichkolwiek zmian w zakresie warunków, oczekiwań lub postaw dotyczących kształcenia na poziomie wyższym, czy też w początkowej fazie ścieżki kariery w organach ścigania.

Zusammenfassung. Das Ziel dieses Aufsatzes ist es, die Fakultät für Recht und Verwaltung der Nationalen Universität für den öffentlichen Dienst und das Aufnahmeverfahren, das die Mitglieder der Generation Z erwartet — und innerhalb dessen diejenigen, die sich für den Offiziersanwärterstatus bewerben wollen — sowie die Abbruchquoten und ihre Ursachen nach erfolgreicher Aufnahme, sowie die vorausgesetzten Basiskompetenzen, die im Rahmen des öffentlichen Dienstes und in der Strafverfolgung erwartet werden, zu erörtern. Die jungen Bewerber*innen, die an der Fakultät Recht und Verwaltung zugelassen werden, sollen einen bedeutenden Teil der zukünftigen Verstärkung des Personals des professionellen Polizeidienstes darstellen, also die Mitglieder der Generation Zstehen nicht nur an den Toren der Hochschulbildung, sondern auch an den Toren des Arbeitsmarktes der Rechtspflege. Mit unserer Studie möchten die Autoren die Zusammenhänge aufzeigen, die sich zwischen den kompetenzbasierten Erwartungen von Strafverfolgungsorganen an die jungen Berufsanfänger und dem Hochschulaufnahmeverfahren sowie den individuellen Wünschen der Bewerber ergeben, sowie den Grad des Kontrastes oder der Synergie des physischen und intellektuellen Status der Studenten in dieser Angelegenheit. Daher kann sich die Frage stellen, ob es notwendig ist, irgendwelche Änderungen in der Reihe von Bedingungen, Erwartungen oder Einstellungen in Bezug auf die Hochschulausbildung oder in der Anfangsphase des Berufsweges der Strafverfolgungsbehörden zu implementieren.

Резюме. Целью данной статьи является представление информции о деятельности Факультета права и администрации Государственной высшей школы общественной службы и процессе набора представителей поколения $Z$, желающих одновременно обращаться за получением статуса курсанта. Авторы представляют данные о количестве случаев и причинах подачи заявления на увольнение после успешного приема кандидата, а также об основных компетенциях, необходимых для работы в государственных и правоохранительных органах. Молодые кандидаты, поступившие на Юридический и административный факультет должны стать важной частью будущих кадров государственной службы, поэтому представитель поколения Z не только стоит на пороге университета, но и выходит на рынок труда правоохранительных органов. Благодаря проведенному исследованию Авторы хотят обратить внимание на существующие связи между ожиданиями правоохранительных органов относительно компетенций молодых людей, начинающих свою профессиональную карьеру, и процессом приема и индивидуальными пожеланиями поступающих, а также уровнем контраста или синергии между физическим и интеллектуальным состоянием студентов. В связи с этим может возникать вопрос о необходимости изменения условий, ожиданий или отношения к высшему образованию, а также на начальном этапе карьеры в правоохранительных органах. 